Review

\title{
Role of Procalcitonin in Management of Infection in Solid Organ Transplantation Recipients: Review
}

Dagan Coppock ${ }^{1}$, Caytlin Deering ${ }^{2}$, Shara Epstein ${ }^{1}$, Dong Heun Lee ${ }^{1, *}$

1. Division of Infectious Diseases and HIV Medicine, Drexel University College of Medicine, USA; EMails: dec77@drexel.edu; Sie25@drexel.edu; dh127@drexel.edu

2. Infectious Diseases Division, University of Toledo College of Medicine and Life Sciences, USA; EMail: Caytlin.Deering@UToledo.Edu

* Correspondence: Dong Heun Lee; E-Mail: dh127@drexel.edu

Academic Editor: Maricar Malinis

Special Issue: Diagnosis and Management of Infections in Solid Organ Transplant Recipients

OBM Transplantation

2019, volume 3 , issue 1

doi:10.21926/obm.transplant.1901054
Received: December 23, 2018

Accepted: February 05, 2019

Published: March 01, 2019

\begin{abstract}
Infections are a common cause of morbidity and mortality in solid organ transplantation (SOT) recipients. Procalcitonin (PCT) has garnered attention as an inflammatory marker that has been shown to be a valuable marker for early identification of systemic bacterial infection. However, interpretation of PCTs value in the different types of infections, transplanted organs, and post-operative courses can be challenging. We review the role of PCT in the management of infections in SOT recipients. First, the PCT level can be elevated immediately after transplant surgery, but those levels decline over one week and do not rise significantly unless an individual develops a systemic bacterial infection. Second, PCT is elevated in systemic bacterial infection, but not in localized bacterial infections or viral infection. Third, procalcitonin does not rise significantly during episodes of acute rejection, but it can be elevated with the use of antithymoglobulin for induction or rejection treatment. While issues remain with the use of PCT as a predictive, it may provide an important piece of information that guides clinical decision-making.
\end{abstract}

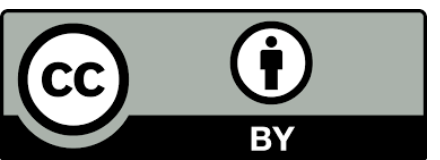

(C) 2019 by the author. This is an open access article distributed under the conditions of the Creative Commons by Attribution License, which permits unrestricted use, distribution, and reproduction in any medium or format, provided the original work is correctly cited. 


\section{Keywords}

Procalcitonin; solid organ transplantation; infection

\section{Introduction}

Infections, as defined by positive culture or biopsy, are a common cause of morbidity and mortality in solid organ transplantation (SOT) recipients [1]. Poor nutritional status, exposure to the health care environment before transplantation and the use of immunosuppressive therapy after the transplantation increase the risk of infections in this population. As is recognized with non-immunosuppressed hosts, early identification of sepsis, with the subsequent administration of empiric antimicrobials and adjustment of immunosuppressant therapy leads to improved patient survival [2-4]. However, patients with suspected sepsis must be distinguished from those with multiple organ dysfunction syndrome of non-infectious etiologies.

A positive fluid or tissue culture remains the gold standard for the diagnosis of bacterial infection. However, cultures are problematic in regard to both sensitivity and specificity. Their lack of sensitivity can lead to missed and delayed diagnoses [5]. From a specificity standpoint, positive cultures can be misleading as the results may represent colonization as opposed to true infection. These diagnostic issues may lead to unnecessary or unnecessarily broad antibiotics that, in turn, may result in complications such as increased antibiotic resistance or Clostridium difficile colitis.

Other than cultures, there are a variety of surrogate markers whose elevation may suggest the presence of infection. These include white blood cell count with differential, temperature, neopterin, interleukin-2 receptor, interleukin-6, interleukin-8, tumor necrosis factor-alpha and Creactive protein (CRP). While an elevated white blood cell count (WBC) is commonly used to predict infection in a normal host, it is not a sensitive marker in the SOT population as the immune system of SOT recipients is blunted from chronic immunosuppression [6, 7]. Beyond WBC, CRP is a well-studied inflammatory marker that can be elevated in the setting of surgery, infection, chronic inflammation, viral illnesses, and even malignancy; however, due to its lack of specificity, it cannot distinguish infection from other potential causes of elevation in SOT recipients $[8,9]$. In particular, differentiating acute rejection from infection is a challenge as both present with similar physiologies and similarly elevated CRPs [10].

In recent years, procalcitonin (PCT) has garnered attention as an inflammatory marker that may aid in the diagnosis of infection and the use of antibiotics [11-13]. In SOT recipients, specifically, procalcitonin has been shown to be a valuable marker for early identification of systemic bacterial infection [14, 15]. As in non-immunosuppressed patients, PCT increases in SOT recipients within three hours of the onset of systemic bacterial infections [16]. Its level is not confounded by graft rejection or concomitant viral infection $[14,16]$. However, in SOT recipients, there is a lack of consensus regarding PCT cutoff values for the identification of infection. Variables such as the type of transplanted organ, immunosuppression use, and the timing of transplant have all shown an effect on PCT levels [17]. Interpretation of PCTs value in the different types of infections, transplanted organs, and post-operative courses can be challenging. In this article, we review the role of PCT in the management of infections in SOT recipients. 


\section{PCT as A Marker for Bacterial Infection}

PCT, a 116 amino acids pro-peptide of calcitonin, is produced under normal conditions in the $C$ cells of the thyroid gland and $\mathrm{K}$ cells of the lung. It does not normally circulate in the bloodstream of healthy individuals [18]. Its clinical relevance was first identified in 1993, when noted to be elevated in children with severe bacterial infections [19], though the mechanism of its production and role in the inflammatory cascade was not well known. In the presence of a systemic bacterial infection, cytokines such as tumor necrosis factor (TNF), interleukin-6 (IL-6), and granulocyte colony-stimulating factor trigger non-neuroendocrine tissues to express the CALC-1 gene, which in turn produces procalcitonin [20-22]. Cytokines associated with infection and bacterial endotoxins slow the conversion of PCT to calcitonin and therefore, thus raising serum PCT concentrations. The lag time for PCT induction is approximately 2 to 4 hours after the onset of systemic bacterial infection, peaking at 24 to 48 hours [23]. After reaching its peak levels, the circulating PCT declines. Its serum half-life is approximately one day, though this may be prolonged by decreased renal clearance. Because PCT elevation is triggered by systemic inflammation, local infections such as abscesses and slowly-evolving infections such as chronic osteomyelitis and tuberculosis may not raise PCT levels [24]. Additionally, PCT is not elevated in viral infections as interferon gamma blocks PCT production. It is not affected by anti-inflammatory agents such as steroids or nonsteroidal anti-inflammatory drugs [17] (Figure 1).

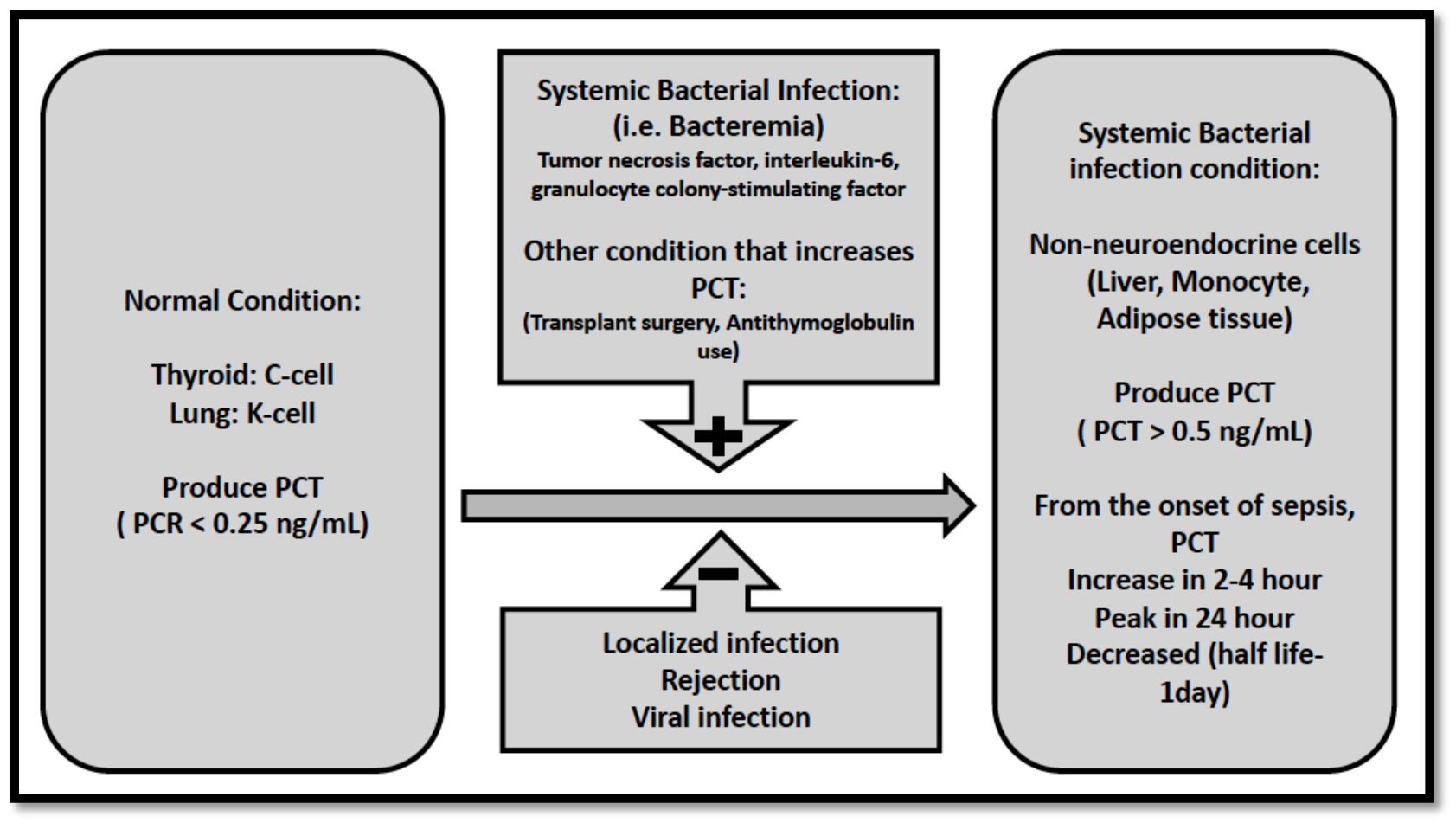

Figure 1 Procalcitonin in response to systemic bacterial infection.

\section{How PCT is Used}

PCT levels can be used in two ways - as individual values with predictive qualities in and of themselves and as a series kinetic values whose predictive nature lies in their change over time. A PCT level higher than $0.5 \mathrm{ng} / \mathrm{mL}$ has a high positive predictive value to rule in systemic bacterial 
infection. A level less than $0.25 \mathrm{ng} / \mathrm{mL}$ has a high negative predictive value to rule out a systemic bacterial infection [25-27]. In the outpatient setting, low cut-off values (e.g. $<0.25 \mathrm{ng} / \mathrm{mL}$ ) have been used to minimize unnecessary antimicrobial therapy [25-27]. In its predictive role as a kinetic value, a decreasing PCT level provides a means to monitor the success of antibacterial therapy. In the intensive care unit (ICU), changes in PCT after the initiation of antibiotics have been used to optimize the duration of antimicrobial therapy. In studies of both general sepsis as well as pneumonia, it has been shown that antibiotics may be safely stopped once PCT levels decrease by more than $80 \%$ from the peak value after antibiotic initiation $[28,29]$. In a systematic review, the use of algorithms based on the change in PCT values, did not increased mortality but did reduce antibiotic exposure [30]. While PCT does not identify the organism to adjust antibiotics, it can be a useful biomarker in deciding to initiate empiric antimicrobial therapy. Combined with the newer rapid organism-identifying technologies such as matrix-assisted laser desorption/ionization time of flight and polymerase chain reaction-based methods, PCT may have an important role in directing antimicrobial use.

\section{PCT Levels in SOT}

PCT is commonly elevated to levels of $10-1000 \mathrm{ng} / \mathrm{mL}$ in severe systemic bacterial infections [9]. In healthy individuals, PCT values are normally below $0.5 \mathrm{ng} / \mathrm{mL}[27,31]$. With its stable biochemical properties, PCT has been used to differentiate systemic bacterial infections in the many clinical settings including the transplant population. In a meta-analysis of seven PCT studies, Yu et al. calculated the predictive value of PCT for infection [32]. PCT demonstrated a sensitivity of $85 \%$ and specificity of $81 \%$ in identifying bacterial infection after transplantation. These parameters were similar to the performance of PCT in evaluating bacteremia in the normal host [8]. When including only liver recipients, the sensitivity and specificity were higher, and, in all patients, the diagnostic value of PCT was not compromised by long-term immunosuppression.

Despite these promising results, there are unique challenges in the interpretation of the PCT levels in SOT recipients, especially at the early transplant course. PCT can be elevated after the major surgery or trauma [33]. Consequently, in heart, lung and liver transplant recipients, PCT is increased in the first post-operative week. However, after that first week, persistently elevated or increasing PCT levels can be used to predict infection [34]. This predictive value has been shown to be superior to CRP for identifying infection [31].

Liver SOT: In liver transplant recipients, PCT levels, in the absence of infection, can be elevated in the first seven days following transplant, with a peak at day two, before declining to a normal level. It is postulated that the influx of bacterial endotoxin from the small bowel during the transplantation and the transiently impaired endotoxin clearance from the graft raises the postoperative PCT level $[35,36]$. Kaido et al. observed that deceased-liver transplant recipients had higher PCT levels than living-liver transplant recipients. This may be explained by an increase in endotoxin production with longer ischemic times.

Beyond the immediate post-operative stage, an elevated PCT has significant associations with infection. Among liver transplant patients with bacteremia, PCT levels are significantly increased compared to patients without bacterial infection, even those with cytomegalovirus (CMV) antigenemia or with acute rejection. Using low and high cut-off values of $0.5 \mathrm{ng} / \mathrm{mL}$ and $2.0 \mathrm{ng} / \mathrm{mL}$, respectively, PCT demonstrated a high negative predictive value of $96 \%$ and a positive predictive 
value of $83 \%$ in the diagnosis of bacteremia [14]. PCT has also been studied to predict catheterrelated bloodstream infections in liver transplant recipients. Chen et al. found 25 patients out of 55 patients who developed catheter-related bloodstream infection had higher PCT levels [37]. Perrakis et al. measured post-operative PCT levels in thirty-two liver transplant recipients. Two patients who had a rapid increase in procalcitonin died. Lower peak procalcitonin levels $(<5 \mathrm{ng} / \mathrm{mL})$ were observed in ten patients, nine of which suffered no complications. Procalcitonin levels greater than $5 \mathrm{ng} / \mathrm{mL}$ were noted to have an eleven-fold higher risk of complications [38]. They concluded that a higher initial PCT might be correlated with post-operative complications and worse outcomes. In another large study of liver transplant recipients, 233 patients were evaluated [39]. PCT was elevated in patients with significant infections, though was not a statistically significant marker for infection. However, it was felt that post-surgical elevation of PCT may have confounded the association as most infections occurred within one week of surgery. Furthermore, localized infections were included in the study and may have confounded the results [39].

Lung SOT: In lung transplant recipients, PCT is elevated in the early transplant period, peaking in the first 24 hours before declining over the next seven days [40]. Elevated PCT levels in the setting of infection have been reported in lung transplant recipients [15, 40, 41]. In 233 patients, Suberviola et al. found that PCT levels above $0.5 \mathrm{ng} / \mathrm{mL}$ on admission and $1.17 \mathrm{ng} / \mathrm{mL}$ on day one after transplantation were significantly associated with an increased risk of infection [15]. Besides infection, PCT has been used to assess pulmonary graft dysfunction, a form of acute lung injury associated with early post-transplantation morality $[42,43]$. Mazo et al. measured PCT in the early period after lung transplantation and found a PCT level measured to be less than $2 \mathrm{ng} / \mathrm{mL}$ with 24 hours of transplant has a highly negative predictive value for grade 3 pulmonary graft dysfunction [44].

Renal SOT: Unlike liver and lung recipients, renal transplant recipients did not see a significant post-operative rise in PCT, possibly due to the comparatively less extensive nature of renal transplant surgery [16]. In a cohort of fifty-seven renal transplant recipients, Eberhard et al. monitored the PCT level during the first six weeks after the transplantation. Seventeen (31\%) of the patients developed an invasive bacterial infection all of whom had a significantly elevated PCT level when compared to ones without infection [45]. Similar findings were seen in a study that evaluated the PCT level in 56 dialysis and 28 renal transplant patients. PCT was significantly associated with infection. Using the cut off value of $0.5 \mathrm{ng} / \mathrm{mL}, \mathrm{PCT}$ had a sensitivity of $78.6 \%$ and specificity of $85.7 \%$ in predicting infection in renal transplant recipients [46]. In renal recipients, PCT was also associated with graft outcomes. Van Ree et al. performed a prospective study evaluating the value of PCT in predicting graft outcome in 575 renal transplant recipients. They measured a PCT level during outpatient visits when the patients had no evidence of infection. Doubling of PCT level from baseline correlated with a three-fold risk of graft failure [47].

Heart SOT: In heart transplant recipients, Madershashian et al. evaluated the association of PCT levels with complications after the heart transplant surgery. Evaluated complications included not only the infection, but also bleeding, the need for repeat surgery, the development of rejection, and the occurrence of acute kidney injury. Among the patients who had a complication, PCT level was elevated on day two $(54.6 \mathrm{ng} / \mathrm{mL}$ vs. $9.1 \mathrm{ng} / \mathrm{mL})$ and day seven $(7.8 \mathrm{ng} / \mathrm{mL}$ vs. $0.6 \mathrm{ng} / \mathrm{mL})$. Similar to the liver and lung transplant recipients, significant elevation of PCT was observed immediately after the surgery in both group [48] (Table 1). 
Table 1 Summary of procalcitonin studies in SOT (Single allograft).

\begin{tabular}{|c|c|c|c|}
\hline $\begin{array}{l}\text { Transplanted } \\
\text { Organ (N) }\end{array}$ & $\begin{array}{l}\text { Article (Author, } \\
\text { country, } \\
\text { published year) }\end{array}$ & $\begin{array}{l}\text { Procalcitonin } \\
\text { Comparison Group }\end{array}$ & Result and Comment \\
\hline \multicolumn{4}{|c|}{ Liver Transplantation } \\
\hline Liver (22) & $\begin{array}{l}\text { Kuse, Germany, } \\
2000[49]\end{array}$ & $\begin{array}{l}\text { Microbiologically } \\
\text { documented infection }\end{array}$ & $\begin{array}{l}\text { Procalcitonin level }>5.9 \mathrm{ng} / \mathrm{mL} \text { had } \\
\text { more likely to have the infection }\end{array}$ \\
\hline Liver (61) & $\begin{array}{l}\text { Fazakas, Hungary, } \\
2003[50]\end{array}$ & $\begin{array}{l}\text { Post-operative } \\
\text { complication }\end{array}$ & $\begin{array}{l}\text { Post-operative day two PCT level } \\
\text { was higher in groups that developed } \\
\text { complication than other groups } \\
\text { ( } 30.6 \mathrm{ng} / \mathrm{mL} \text { vs. } 4.8 \mathrm{ng} / \mathrm{mL} \text { ) }\end{array}$ \\
\hline Liver (67) & $\begin{array}{l}\text { Eyraud, France, } \\
2008[35]\end{array}$ & Infection & $\begin{array}{l}\text { High peak PCT level was associated } \\
\text { with infection and cardiac arrest of } \\
\text { donor }\end{array}$ \\
\hline Liver (64) & $\begin{array}{l}\text { Prieto, Spain, } \\
2008[51]\end{array}$ & Infection & $\begin{array}{l}23 \text { who developed infection had } \\
\text { higher PCT level than ones did not } \\
\text { have an infection (cut off } 1.92 \\
\mathrm{ng} / \mathrm{mL} \text { ) }\end{array}$ \\
\hline Liver (135) & $\begin{array}{l}\text { Van den Broek, } \\
\text { Germany } 2010 \\
{[39]}\end{array}$ & $\begin{array}{l}\text { Clinically significant } \\
\text { infection ( } N=30,8 \\
\text { pulmonary infection, } \\
9 \text { intraabdominal } \\
\text { infection, } 13 \\
\text { bacteremia) }\end{array}$ & $\begin{array}{l}\text { Patient with clinically significant } \\
\text { infection had higher peak PCT than } \\
\text { non-infected, but it was not an } \\
\text { independent marker. }\end{array}$ \\
\hline Liver (32) & $\begin{array}{l}\text { Perrakis, } \\
\text { Germany, } 2010 \\
{[38]}\end{array}$ & $\begin{array}{l}\text { Noncomplicated vs. } \\
\text { complicated group }\end{array}$ & $\begin{array}{l}\text { Peak PCT level }>5 \mathrm{ng} / \mathrm{mL} \text { had } \\
\text { increased odds ratio of a } \\
\text { complication } 11.2 \text {. }\end{array}$ \\
\hline Liver (55) & $\begin{array}{l}\text { Chen, China, } 2011 \\
\text { [37] }\end{array}$ & $\begin{array}{l}\text { Catheter-related } \\
\text { bloodstream infection }\end{array}$ & $\begin{array}{l}25(45 \%) \text { who developed catheter- } \\
\text { related bloodstream infection had } \\
\text { higher PCT level than those who did } \\
\text { not. (cut off value } 3.1 \mathrm{ng} / \mathrm{mL} \text { ) }\end{array}$ \\
\hline Liver (34) & $\begin{array}{l}\text { Grammatikopoul } \\
\text { os, United } \\
\text { Kingdom, } 2012 \\
\text { [52] }\end{array}$ & $\begin{array}{l}\text { Fever, } 22(66 \%) \\
\text { developed the } \\
\text { infection }\end{array}$ & $\begin{array}{l}\text { PCT levels were significantly higher } \\
\text { in bacterial and fungal infection in } \\
\text { comparison to other inflammatory } \\
\text { markers (CRP, IL-6). }\end{array}$ \\
\hline Liver (104) & $\begin{array}{l}\text { Kaido, Japan } 2014 \\
\text { [14] }\end{array}$ & $\begin{array}{l}\text { Post-operative } \\
\text { Bacteremia } \\
\text { CMV antigenemia } \\
\text { Acute cellular } \\
\text { rejection }\end{array}$ & $\begin{array}{l}\text { Increased (Deceased-donor had } \\
\text { higher level increase than living } \\
\text { donor) in the first } 7 \text { days, peak in } \\
\text { day } 2 \text { to } 3 \text {. } \\
45 \text { ( } 43 \% \text { ) out of } 104 \text { patients with } \\
\text { bacteremia had higher PCT level. } \\
\text { PCT level did not increased in CMV } \\
\text { antigenemia compared to } \\
\text { bacteremia ( } 0.53 \mathrm{ng} / \mathrm{mL} \text { vs } 5.71 \\
\text { ng/mL) } \\
\text { PCT level did not increased in acute }\end{array}$ \\
\hline
\end{tabular}




\begin{tabular}{|c|c|c|c|}
\hline & & & $\begin{array}{l}\text { rejection compared to bacteremia } \\
(0.42 \mathrm{ng} / \mathrm{mL} \text { vs } 5.71 \mathrm{ng} / \mathrm{mL})\end{array}$ \\
\hline Liver (65) & $\begin{array}{l}\text { Gur, Turkey } 2017 \\
\text { [53] }\end{array}$ & $\begin{array}{l}\text { Infection by culture } \\
\text { positive versus } \\
\text { control }\end{array}$ & $\begin{array}{l}\text { Higher PCT level ( } 20.5 \mathrm{ng} / \mathrm{ml} \text { vs. } 2 \\
\mathrm{ng} / \mathrm{ml} \text { ) in the infection group than } \\
\text { the control group }\end{array}$ \\
\hline \multicolumn{4}{|c|}{ Lung Transplantation } \\
\hline Lung (25) & $\begin{array}{l}\text { Suberviola, Spain, } \\
2012[41]\end{array}$ & $\begin{array}{l}\text { Infection versus non- } \\
\text { infection }\end{array}$ & $\begin{array}{l}\text { Six developed infections ( } 3 \\
\text { pneumonia, } 2 \text { bacteremia, } 1 \\
\text { peritonitis) had higher PCT than } \\
\text { control (cut off } 8.18 \mathrm{ng} / \mathrm{mL} \text { ) }\end{array}$ \\
\hline Lung (26) & $\begin{array}{l}\text { Desmard, French, } \\
2015 \text { [40] }\end{array}$ & Respiratory infection & $\begin{array}{l}\text { Doubling PCT level was associated } \\
\text { with respiratory infection (RR } 4.2 \text {, } \\
95 \% \mathrm{Cl}(1.95 \text { to } 9.03 \text { ) }\end{array}$ \\
\hline Lung (233) & $\begin{array}{l}\text { Suberviola, Spain } \\
2017[15]\end{array}$ & Infection & $\begin{array}{l}\text { PCT levels above the median } \\
(0.5 \mathrm{ng} / \mathrm{mL} \text { on admission or } 1.17 \\
\mathrm{ng} / \mathrm{mL} \text { on day } 1) \text { were associated } \\
\text { with an increased risk of infection }\end{array}$ \\
\hline Lung (100) & $\begin{array}{l}\text { Mazo, Spain } 2018 \\
{[44]}\end{array}$ & $\begin{array}{l}\text { ICU survival, } \\
\text { pulmonary graft } \\
\text { dysfunction }\end{array}$ & $\begin{array}{l}\mathrm{PCT}<2 \mathrm{ng} / \mathrm{mL} \text { within } 24 \text { hours of } \\
\text { transplant has a high predictive } \\
\text { value to exclude grade } 3 \text { pulmonary } \\
\text { graft dysfunction ( } 97 \%) \text { and for ICU } \\
\text { mortality }(100 \%)\end{array}$ \\
\hline \multicolumn{4}{|c|}{ Heart transplantation } \\
\hline Heart (52) & $\begin{array}{l}\text { Madershahian, } \\
\text { Germany, } 2008 \\
{[54]}\end{array}$ & $\begin{array}{l}\text { Event (complication } \\
\text { including bleeding, } \\
\text { acute kidney injury, } \\
\text { infection, rejection) }\end{array}$ & $\begin{array}{l}28 \text { pts eventful group had lower PCT } \\
\text { than } 24 \text { pts with an event on the } \\
\text { second day and day seven }\end{array}$ \\
\hline \multicolumn{4}{|c|}{ Kidney Transplantation } \\
\hline Kidney (57) & $\begin{array}{l}\text { Eberhard, } \\
\text { Germany,1998 } \\
{[45]}\end{array}$ & $\begin{array}{l}17 \text { patients with } \\
\text { invasive bacterial } \\
\text { infection compared } \\
\text { with } 30 \text { non-infected }\end{array}$ & $\begin{array}{l}\text { PCT was elevated with invasive } \\
\text { bacterial infection }\end{array}$ \\
\hline Kidney (575) & $\begin{array}{l}\text { Van Ree, } \\
\text { Netherland, } 2009 \\
{[47]}\end{array}$ & $\begin{array}{l}\text { Graft failure } \\
\text { (Procalcitonin level } \\
\text { obtained at } \\
\text { outpatient at the time } \\
\text { of no active infection) }\end{array}$ & $\begin{array}{l}\text { Doubling PCT level from baseline } \\
\text { was associated with a three-fold } \\
\text { increase of graft failure. }\end{array}$ \\
\hline Kidney (406) & $\begin{array}{l}\text { Dizdar, Turkey, } \\
2014 \text { [55] }\end{array}$ & $\begin{array}{l}82(20 \%) \text { patients } \\
\text { developed pneumonia }\end{array}$ & $\begin{array}{l}\mathrm{PCT} \text { level }>8.8 \mathrm{ng} / \mathrm{mL} \text { increased the } \\
\text { risk of death from pneumonia }\end{array}$ \\
\hline
\end{tabular}

\section{Non-Infectious Causes of PCT Elevation in SOT Recipients}

There are a variety of non-infectious conditions that can lead to an elevation of serum PCT in SOT recipients. These includes cirrhosis, inhalational injury, obstructive pancreatitis, autoimmune disorders, trauma, ischemia, malignancy, rhabdomyolysis and the use of immunosuppressive drugs [17, 34, 45, 56-58]. As with transplant itself, other major surgeries result in an elevation of PCT levels, especially in the first 24-48 hours after surgery [59]. Transient gut translocation of 
bacterial products into the systemic circulation may also lead to a rise in PCT, even if the translocation does not lead to other sequelae suggestive of infection [34, 57]. While the above may confound the clinical utility of PCT as a predictor of bacterial infection, acute rejection typically demonstrates only a modest increase in PCT $[9,60]$.

\section{The Effect of Antithymocyte Globulin (ATG) on PCT Levels}

Antithymocyte globulin (ATG) used during induction or rejection treatment can raise PCT levels $[54,61,62]$. In heart transplant recipients, PCT levels have been shown to increase after ATG induction, though trend down on further dosing [54]. Similar PCT kinetics have been observed in renal transplant recipients receiving ATG, though those who received interleukin-2 receptor blockade did not demonstrate an elevation in PCT levels [61]. For those receiving ATG, the early elevation in PCT may have been confounded by post-surgical elevation of procalcitonin. However, SOT recipients treated for acute rejection, distant from the time of transplantation, had similar PCT elevation after ATG administration $[45,61,63]$. The mechanism behind this elevation is thought to be twofold. First, ATG leads to transient elevation of cytokines such as TNF alpha and interleukin-10, which can in turn trigger PCT production. Also, cytokines produced in the setting of ATG can transiently increase gut permeability with associated endotoxin translocation. Endotoxin, as had been noted, leads to a rise in PCT levels [61]. Beyond ATG, other common chronic immunosuppression like cyclosporine, tacrolimus, azathioprine, and steroids do not affect the baseline PCT level [16, 26, 44, 60,64]. If the degree of immunosuppression and the type of immunosuppression are not changed, the dynamics of the PCT level should remain stable and can be used as a biomarker to differentiate systemic bacterial infection.

\section{Remaining Challenges}

There are areas not well described regarding PCT use in SOT recipients. PCT is not well studied in specific types of infection in different allograft SOT recipients. Most of the studies described above were retrospective and had different definitions of infection. Therefore, it is hard to generalize regarding the value of PCT to identify risk for infection in individual patients. Further, the degree of PCT elevation in different pathogens, by organism or organism type, was not defined. While it is generally elevated in systemic bacterial infections, it remains an insensitive test for predicting or identifying localized infection. Also, if PCT is to be used post-operatively for screening or monitoring, a patient's baseline, pre-operative PCT level, history of other recent surgeries, and the presence of rejection may all confound the utility of PCT monitoring. Furthermore, the length and most appropriate time window for screening is unknown, which may further affect the clinical usefulness of the test. While all of the above questions relate to PCT levels in recipients, another area of interest yet to be explored is the association of donor PCT levels on recipient outcomes. An exploration of the above issues may help establish the value of measuring PCT levels in transplant patients.

\section{Summary}

The use of PCT holds potential as a modality for assessing the presence of systemic bacterial infection in SOT recipients. At this stage, there are a few facts to consider if using PCT to predict 
the presence of infections in SOT recipients. First, the PCT level can be elevated immediately after transplant surgery, especially in heart, lung, and liver transplant recipients. However, those levels decline over one week and do not rise significantly unless an individual develops a systemic bacterial infection. Second, PCT is elevated in systemic bacterial infection, but not in localized bacterial infections or viral infection. Therefore, clinicians should still take care to rule out localized bacterial infections or viral infections in patients with low PCT levels. Third, procalcitonin does not rise significantly during episodes of acute rejection, but it can be elevated with the use of ATG for induction or rejection treatment. However, PCT is not affected by other immunomodulators. While issues remain with the use of PCT as a predictive, it may provide an important piece of information that guides clinical decision-making.

\section{Author Contributions}

All authors contributed in critical review of the literature, writing of the manuscript and approval of final version.

\section{Competing Interests}

The authors have declared that no competing interests exist.

\section{References}

1. Kaido T, Egawa H, Tsuji H, Ashihara E, Maekawa T, Uemoto S. In-hospital mortality in adult recipients of living donor liver transplantation: experience of 576 consecutive cases at a single center. Liver Transplant. 2009; 15: 1420-1425.

2. Levy MM, Evans LE, Rhodes A. The Surviving Sepsis Campaign Bundle: 2018 Update. Crit Care Med. 2018; 46: 997-1000.

3. Hamandi B, Husain S, Humar A, Papadimitropoulos EA. Impact of infectious disease consultation on the clinical and economic outcomes of solid organ transplant recipients admitted for infectious complications. Clin Infect Dis. 2014; 59: 1074-1082.

4. Hamandi B, Holbrook AM, Humar A, Brunton J, Papadimitropoulos EA, Wong GG, et al. Delay of adequate empiric antibiotic therapy is associated with increased mortality among solidorgan transplant patients. Am J Transplant. 2009; 9 : 1657-1665.

5. Rangel-Frausto MS, Pittet $D$, Costigan M, Hwang T, Davis CS, Wenzel RP. The natural history of the systemic inflammatory response syndrome (SIRS). A prospective study. JAMA. 1995; 273: 117-123.

6. Fishman JA. Infection in solid-organ transplant recipients. N Engl J Med. 2007; 357: 2601-2614.

7. Sawyer RG, Crabtree TD, Gleason TG, Antevil JL, Pruett TL. Impact of solid organ transplantation and immunosuppression on fever, leukocytosis, and physiologic response during bacterial and fungal infections. Clin Transplant. 1999; 13: 260-265.

8. Simon L, Gauvin F, Amre DK, Saint-Louis P, Lacroix J. Serum procalcitonin and C-reactive protein levels as markers of bacterial infection: a systematic review and meta-analysis. Clin Infect Dis. 2004; 39: 206-217.

9. Oczenski W, Fitzgerald RD, Schwarz S. Procalcitonin: A new parameter for the diagnosis of bacterial infection in the peri-operative period. Eur J Anaesthesiol. 1998; 15: 202-209. 
10. Lempert N, Laffin RJ, Fitzgerald K, Freed BM. Elevation of serum C-reactive protein levels during graft rejection. Transplant Proc. 1987; 19: 1683-1685.

11. Liu D, Su L, Han G, Yan P, Xie L. Prognostic value of procalcitonin in adult patients with sepsis: A systematic review and meta-analysis. PLoS One. 2015; 10: e0129450.

12. Schuetz $P$, Christ-Crain M, Thomann R, Falconnier C, Wolbers M, Widmer I, et al. Effect of procalcitonin-based guidelines vs standard guidelines on antibiotic use in lower respiratory tract infections: The ProHOSP randomized controlled trial. JAMA. 2009; 302: 1059-1066.

13. Bouadma L, Luyt CE, Tubach F, Cracco C, Alvarez A, Schwebel C, et al. Use of procalcitonin to reduce patients' exposure to antibiotics in intensive care units (PRORATA trial): A multicentre randomised controlled trial. Lancet. 2010; 375: 463-474.

14. Kaido T, Ogawa K, Fujimoto $Y$, Mori A, Hatano E, Okajima H, et al. Perioperative changes of procalcitonin levels in patients undergoing liver transplantation. Transplant Infect Dis. 2014; 16: 790-796.

15. Suberviola B, Rellan L, Riera J, Iranzo R, Garcia Campos A, Robles JC, et al. Role of biomarkers in early infectious complications after lung transplantation. PLoS One. 2017; 12: e0180202.

16. Jaresova M, Striz I, Cermakova J, Lacha J, Sedlacek J, Mudra K, et al. Serum procalcitonin concentrations in transplant patients with acute rejection and bacterial infections. Immunol Lett. 1999; 69: 355-358.

17. Savas Bozbas S, Er Dedekarginoglu B, Ulubay G, Haberal M. Role of serum procalcitonin levels in solid-organ transplant patients. Exp Clin Transplant. 2016; 14: 116-120.

18. Becker KL, Nylen ES, White JC, Muller B, Snider RH Jr. Clinical review 167: Procalcitonin and the calcitonin gene family of peptides in inflammation, infection, and sepsis: a journey from calcitonin back to its precursors. J Clin Endocrinol Metab. 2004; 89: 1512-1525.

19. Assicot M, Gendrel D, Carsin H, Raymond J, Guilbaud J, Bohuon C. High serum procalcitonin concentrations in patients with sepsis and infection. Lancet. 1993; 341: 515-518.

20. Nijsten MW, Olinga P, The TH, de Vries EG, Koops HS, Groothuis GM, et al. Procalcitonin behaves as a fast responding acute phase protein in vivo and in vitro. Crit Care Med. 2000; 28: 458-461.

21. Oberhoffer M, Stonans I, Russwurm S, Stonane E, Vogelsang H, Junker U, et al. Procalcitonin expression in human peripheral blood mononuclear cells and its modulation by lipopolysaccharides and sepsis-related cytokines in vitro. J Lab Clin Med. 1999; 134: 49-55.

22. Linscheid P, Seboek D, Schaer DJ, Zulewski H, Keller U, Muller B. Expression and secretion of procalcitonin and calcitonin gene-related peptide by adherent monocytes and by macrophage-activated adipocytes. Crit Care Med. 2004; 32: 1715-1721.

23. Meisner M, Tschaikowsky K, Schnabel S, Schmidt J, Katalinic A, Schuttler J. Procalcitonin-influence of temperature, storage, anticoagulation and arterial or venous asservation of blood samples on procalcitonin concentrations. Eur J Clin Chem Clin Biochem. 1997; 35: 597601.

24. Meisner M. Update on procalcitonin measurements. Ann Lab Med. 2014; 34: 263-273.

25. Briel M, Schuetz P, Mueller B, Young J, Schild U, Nusbaumer C, et al. Procalcitonin-guided antibiotic use vs a standard approach for acute respiratory tract infections in primary care. Arch Intern Med. 2008; 168: 2000-2007; discussion 7-8. 
26. Stolz D, Christ-Crain M, Bingisser R, Leuppi J, Miedinger D, Muller C, et al. Antibiotic treatment of exacerbations of COPD: a randomized, controlled trial comparing procalcitoninguidance with standard therapy. Chest. 2007; 131: 9-19.

27. Christ-Crain M, Jaccard-Stolz D, Bingisser R, Gencay MM, Huber PR, Tamm M, et al. Effect of procalcitonin-guided treatment on antibiotic use and outcome in lower respiratory tract infections: cluster-randomised, single-blinded intervention trial. Lancet. 2004; 363: 600-607.

28. Stolz D, Smyrnios N, Eggimann P, Pargger H, Thakkar N, Siegemund M, et al. Procalcitonin for reduced antibiotic exposure in ventilator-associated pneumonia: a randomised study. Eur Respir J. 2009; 34: 1364-1375.

29. Hohn A, Schroeder S, Gehrt A, Bernhardt K, Bein B, Wegscheider K, et al. Procalcitonin-guided algorithm to reduce length of antibiotic therapy in patients with severe sepsis and septic shock. BMC Infect Dis. 2013; 13: 158.

30. Schuetz P, Muller B, Christ-Crain M, Stolz D, Tamm M, Bouadma L, et al. Procalcitonin to initiate or discontinue antibiotics in acute respiratory tract infections. Evid Based Child Health. 2013; 8: 1297-1371.

31. Cooper D, Sharples L, Cornelissen J, Wallwork J, Alexander G, Trull A. Comparison between procalcitonin, serum amyloid $A$, and C-reactive protein as markers of serious bacterial and fungal infections after solid organ transplantation. Transplant Proc. 2001; 33: 1808-1810.

32. $Y u X Y$, Wang $Y$, Zhong $H$, Dou QL, Song $Y L$, Wen $H$. Diagnostic value of serum procalcitonin in solid organ transplant recipients: a systematic review and meta-analysis. Transplant Proc. 2014; 46: 26-32.

33. Meisner $\mathrm{M}$, Adina $\mathrm{H}$, Schmidt J. Correlation of procalcitonin and C-reactive protein to inflammation, complications, and outcome during the intensive care unit course of multipletrauma patients. Crit Care. 2006; 10: R1.

34. Sandkovsky U, Kalil AC, Florescu DF. The use and value of procalcitonin in solid organ transplantation. Clin Transplant. 2015; 29: 689-696.

35. Eyraud D, Ben Ayed S, Tanguy ML, Vezinet C, Siksik JM, Bernard M, et al. Procalcitonin in liver transplantation: are high levels due to donors or recipients? Crit Care. 2008; 12: R85.

36. Kretzschmar $M$, Kruger A, Schirrmeister W. Hepatic ischemia-reperfusion syndrome after partial liver resection (LR): hepatic venous oxygen saturation, enzyme pattern, reduced and oxidized glutathione, procalcitonin and interleukin-6. Exp Toxicol Pathol. 2003; 54: 423-431.

37. Chen J, Wang Y, Shen Z, Zhu Z, Song Y, Han R. Early diagnostic value of plasma PCT and BG assay for CRBSI after OLT. Transplant Proc. 2011; 43: 1777-1779.

38. Perrakis A, Yedibela S, Schellerer V, Hohenberger W, Muller V. Procalcitonin in the setting of complicated postoperative course after liver transplantation. Transplant Proc. 2010; 42: 4187-4190.

39. van den Broek MA, Olde Damink SW, Winkens B, Broelsch CE, Malago M, Paul A, et al. Procalcitonin as a prognostic marker for infectious complications in liver transplant recipients in an intensive care unit. Liver Transplant. 2010; 16: 402-410.

40. Desmard M, Benbara A, Boudinet S, Mal H, Dehoux M, Thabut G, et al. Post-operative kinetics of procalcitonin after lung transplantation. J Heart Lung Transplant. 2015; 34: 189-194.

41. Suberviola B, Castellanos-Ortega A, Ballesteros MA, Zurbano F, Naranjo S, Minambres E. Early identification of infectious complications in lung transplant recipients using procalcitonin. Transplant Infect Dis. 2012; 14: 461-467. 
42. Christie JD, Carby M, Bag R, Corris P, Hertz M, Weill D, et al. Report of the ISHLT Working Group on Primary Lung Graft Dysfunction part II: definition. A consensus statement of the International Society for Heart and Lung Transplantation. J Heart Lung Transplant. 2005; 24: 1454-1459.

43. de Perrot M, Liu M, Waddell TK, Keshavjee S. Ischemia-reperfusion-induced lung injury. Am J Respir Crit Care Med. 2003; 167: 490-511.

44. Mazo C, Borgatta B, Pont T, Sandiumenge A, Moyano S, Roman A, et al. Procalcitonin accurately predicts lung transplant adults with low risk of pulmonary graft dysfunction and intensive care mortality. J Crit Care. 2018; 44: 142-147.

45. Eberhard OK, Haubitz M, Brunkhorst FM, Kliem V, Koch KM, Brunkhorst R. Usefulness of procalcitonin for differentiation between activity of systemic autoimmune disease (systemic lupus erythematosus/systemic antineutrophil cytoplasmic antibody-associated vasculitis) and invasive bacterial infection. Arthritis Rheum. 1997; 40: 1250-1256.

46. Dumea R, Siriopol D, Hogas S, Mititiuc I, Covic A. Procalcitonin: Diagnostic value in systemic infections in chronic kidney disease or renal transplant patients. Int Urol Nephrol. 2014; 46: 461-468.

47. van Ree RM, de Vries AP, Oterdoom LH, Seelen MA, Gansevoort RT, Schouten JP, et al. Plasma procalcitonin is an independent predictor of graft failure late after renal transplantation. Transplantation. 2009; 88: 279-287.

48. Madershahian N, Wittwer T, Strauch J, Wippermann J, Rahmanian P, Franke UF, et al. Kinetic of procalcitonin in the early postoperative course following heart transplantation. J Card Surg. 2008; 23: 468-473.

49. Kuse ER, Langefeld I, Jaeger K, Kulpmann WR. Procalcitonin-a new diagnostic tool in complications following liver transplantation. Intensive Care Med. 2000; 26: S187-S192.

50. Fazakas J, Gondos T, Varga M, Sarvary E, Horovitz P, Perner F. Analysis of systemic and regional procalcitonin serum levels during liver transplantation. Transplant Int. 2003; 16: 465470.

51. Prieto B, Llorente E, Gonzalez-Pinto I, Alvarez FV. Plasma procalcitonin measured by timeresolved amplified cryptate emission (TRACE) in liver transplant patients. A prognosis marker of early infectious and non-infectious postoperative complications. Clin Chem Lab Med. 2008; 46: 660-666.

52. Grammatikopoulos T, Dhawan A, Bansal S, Wade J, Sherwood R, Dew T, et al. Baseline evaluation of serum markers of inflammation and their utility in clinical practice in paediatric liver transplant recipients. Clin Res Hepatol Gastroenterol. 2012; 36: 365-370.

53. Gur A, Oguzturk $H$, Kose A, Turtay MG, Ersan V, Bayindir $Y$, et al. Prognostic value of procalcitonin, CRP, serum amyloid A, lactate and IL-6 markers in liver transplant patients admitted to ED with suspected infection. In Vivo. 2017; 31: 1179-1185.

54. Madershahian N, Wittwer T, Franke UF, Wippermann J, Strauch J, Groetzner J, et al. Effect of induction therapy on kinetic of procalcitonin following uncomplicated heart transplantation. J Card Surg. 2007; 22: 199-202.

55. Dizdar OS, Ersoy A, Akalin H. Pneumonia after kidney transplant: incidence, risk factors, and mortality. Exp Clin Transplant. 2014; 12: 205-211. 
56. Rau B, Steinbach G, Baumgart K, Gansauge F, Grunert A, Beger HG. The clinical value of procalcitonin in the prediction of infected necrosis in acute pancreatitis. Intensive Care Med. 2000; 26: S159-S164.

57. Becker KL, Snider R, Nylen ES. Procalcitonin assay in systemic inflammation, infection, and sepsis: clinical utility and limitations. Crit Care Med. 2008; 36: 941-952.

58. Jimeno A, Garcia-Velasco A, del Val O, Gonzalez-Billalabeitia E, Hernando S, Hernandez R, et al. Assessment of procalcitonin as a diagnostic and prognostic marker in patients with solid tumors and febrile neutropenia. Cancer. 2004; 100: 2462-2469.

59. Lindberg $M$, Hole A, Johnsen $H$, Asberg A, Rydning A, Myrvold HE, et al. Reference intervals for procalcitonin and C-reactive protein after major abdominal surgery. Scand J Clin Lab Invest. 2002; 62: 189-194.

60. Hammer S, Meisner F, Dirschedl P, Fraunberger P, Meiser B, Reichart B, et al. Procalcitonin for differential diagnosis of graft rejection and infection in patients with heart and/or lung grafts. Intensive Care Med. 2000; 26: S182-S186.

61. Sabat R, Hoflich C, Docke WD, Oppert M, Kern F, Windrich B, et al. Massive elevation of procalcitonin plasma levels in the absence of infection in kidney transplant patients treated with pan-T-cell antibodies. Intensive Care Med. 2001; 27: 987-991.

62. Zazula R, Prucha M, Tyll T, Kieslichova E. Induction of procalcitonin in liver transplant patients treated with anti-thymocyte globulin. Crit Care. 2007; 11: R131.

63. Kuse ER, Jaeger K. Procalcitonin increase after anti-CD3 monoclonal antibody therapy does not indicate infectious disease. Transplant Int. 2001; 14: 55.

64. Staehler M, Hammer C, Meiser B, Reichart B. Procalcitonin: A new marker for differential diagnosis of acute rejection and bacterial infection in heart transplantation. Transplant Proc. 1997; 29: 584-585.

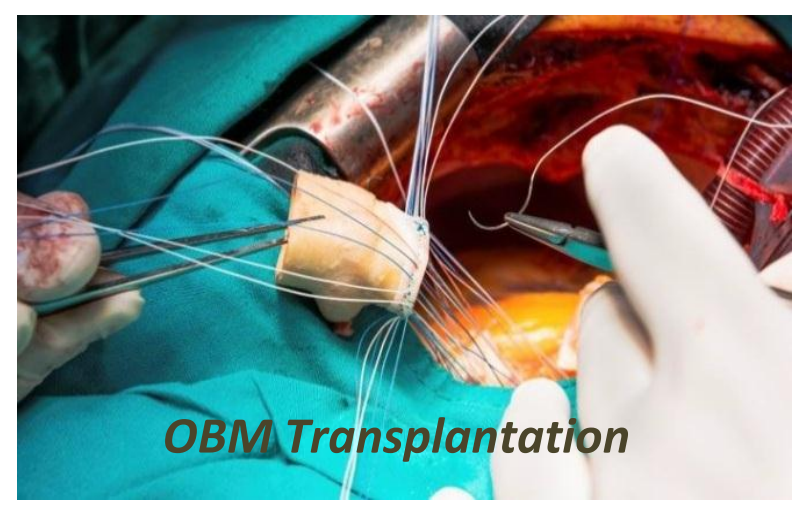

Enjoy OBM Transplantation by:

1. Submitting a manuscript

2. Joining in volunteer reviewer bank

3. Joining Editorial Board

4. Guest editing a special issue

For more details, please visit:

http://www.lidsen.com/journals/transplantation 